\title{
Staphylococcus epidermidis Induces Complement Activation, Tumor Necrosis Factor and Interleukin-1, a Shock-like State and Tissue Injury in Rabbits Without Endotoxemia Comparison to Escherichia coli
}

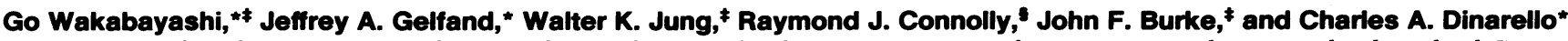
*Department of Medicine, Division of Geographic Medicine and Infectious Disease, Tufts University and New England Medical Center Hospital, Boston, Massachusetts 02111; ${ }^{\ddagger}$ Department of Surgery, Harvard Medical School and Massachusetts General Hospital, Boston, Massachusetts 02114; and ${ }^{8}$ Department of Surgery, Tufts University and New England Medical Center Hospital, Boston, Massachusetts 02111

\begin{abstract}
Tumor necrosis factor (TNF) and IL-1 are thought to mediate many of the pathophysiologic changes of endotoxemia and Gram-negative bacteremia. In these studies, heat-killed Staphylococcus epidermidis were infused into rabbits to determine whether an endotoxin (LPS)-free microorganism also elicits cytokinemia and the physiologic abnormalities seen in Gramnegative bacteremia. $S$. epidermidis induced complement activation, circulating TNF and IL-1, and hypotension to the same degree as did one-twentieth the number of heat-killed Escherichia coli. Circulating IL-1 $\beta$ levels had a greater correlation coefficient $(r=0.81, P<0.001)$ with the degree of hypotension than TNF levels $(r=0.48, P<0.02)$. Leukopenia, thrombocytopenia, diffuse pulmonary capillary aggregation of neutrophils, and hepatic necrosis with neutrophil infiltration were observed to the same extent after either $S$. epidermidis or $E$. coli infusion. However, S. epidermidis infusion did not induce significant $(<60 \mathrm{pg} / \mathrm{ml})$ endotoxemia, whereas $E$. coli infusion resulted in high $(11,000 \mathrm{pg} / \mathrm{ml})$ serum endotoxin levels. $S$. epidermidis, $\boldsymbol{E}$. coli, LPS, or $\boldsymbol{S}$. epidermidis-derived lipoteichoic acid (LTA) induced TNF and IL-1 from blood mononuclear cells in vitro. $E$. coli organisms and LPS were at least 100 -fold more potent than $S$. epidermidis or LTA. Thus, a shock-like state with similar levels of complement activation as well as circulating levels of IL-1 and TNF were observed following either $S$. epidermidis or $E$. coli. These data provide further evidence that host factors such as IL-1 and TNF are common mediators of the septic shock syndrome regardless of the organism. (J. Clin. Invest. 1991. 87:1925-1935.) Key words: C5a • cytokine $\bullet$ disseminated intravascular coagulation • lipoteichoic acid $\cdot$ neutrophil aggregation
\end{abstract}

This work was presented in part at the American Federation of Clinical Research, Washington, DC, May, 1990.

Address correspondence to Dr. Charles A. Dinarello, New England Medical Center Hospital, 750 Washington Street, Boston, MA 0211.

Received for publication 23 April 1990 and in revised form 11 January 1991.

J. Clin. Invest.

(c) The American Society for Clinical Investigation, Inc. $0021-9738 / 91 / 06 / 1925 / 11 \quad \$ 2.00$

Volume 87, June 1991, 1925-1935

\section{Introduction}

Tumor necrosis factor (TNF) ${ }^{1}$ and IL-1 induce hemodynamic shock in experimental animals (1-4); the combined infusion of IL-1 and TNF produces tissue damage and metabolic derangements similar to those associated with injury and sepsis in humans (3-5). Furthermore, serum TNF and IL- $1 \beta$ levels are elevated in patients with Gram-negative bacteremia, and correlate with severity of the sepsis (6). Other peptide and lipid mediators, such as anaphylatoxins, arachidonic acid metabolites, and platelet-activating factor (PAF) also contribute to the pathophysiologic changes of Gram-negative bacteremia (7-14).

The importance of TNF in the pathogenesis of the septic shock syndrome has been shown using neutralizing antibodies against TNF that prevent lethal endotoxic and septic shock due to $E$. coli bacteremia (15-18). Thus, the Gram-negative septic shock syndrome appears to require TNF. However, there are no experimental sepsis models in which cytokines have been shown to play a role in the absence of endotoxemia. Grampositive organisms offer an opportunity to study cytokine production and the shock syndrome independent of endotoxin.

Staphylococcus epidermidis can be a cause of sepsis and shock (19-24). Moreover, the incidence of bacteremia due to this organism has increased during last two decades $(19,22$, 23). Septic shock was observed in 15-22\% of patients with positive blood cultures for $S$. epidermidis (21-23) and the crude mortality rate of sepsis caused by $S$. epidermidis has ranged from $18.5 \%$ to $57 \%$ (19-21). Natanson and colleagues demonstrated that Staphylococcus aureus was capable of producing cardiovascular dysfunctions in the dog similar to those seen in humans (25). Decreased mean arterial pressure, decreased ejection fraction, normal or increased stroke volume index, and cardiac index were observed during $S$. aureus sepsis in the absence of endotoxemia. A similar pattern was observed using viable or killed $S$. aureus. The authors concluded that sepsis, whether due to Gram-positive or Gram-negative organisms, induced similar hemodynamic dysfunctions, were likely due to a final common pathway of inflammatory mediators, and that endotoxin was not necessary for septic shock to occur (25).

1. Abbreviations used in this paper: $\mathrm{CO}$, cardiac output; CVP, central venous pressure; LTA, lipoteichoic acid; MAP, mean arterial pressure; PAF, platelet-activating factor; PMB, polymoxin B; SVR, systemic vascular resistance; TNF, tumor necrosis factor. 
In this study, we have employed a similar experimental approach comparing the effects of Gram-positive heat-killed $S$. epidermidis to those of killed $E$. coli organisms in rabbits. We used rabbits to measure circulating levels of TNF (26) and of IL- $1 \alpha$ and $\beta$ by specific radioimmunoassays (27). These methods allowed us to test the hypothesis that circulating cytokine levels rather than levels of endotoxin would correlate with hemodynamic changes. We also investigated the ability of lipoteichoic acid (LTA) derived from $S$. epidermidis and LPS derived from $E$. coli to induce TNF and IL-1 from rabbit cells in vitro. The in vivo experiments were designed to compare complement activation, TNF and IL-1 production, and the appearance of a shock-like state following either $S$. epidermidis or $E$. coli. We found that injection of either organism results in a septic shock-like syndrome by inducing similar levels of TNF and IL-1; these studies provide further evidence that cytokine production and shock occur without a requirement for endotoxemia.

\section{Methods}

Bacterial preparation. S. epidermidis (a blood culture isolate) and $E$. coli (0127: B8, American Type Culture Collection, Rockville, MD) were inoculated into brain heart-infusion broth (BBL Microbiology Systems, Becton, Dickinson, \& Co., Cockeysville, MD) prepared in pyrogen-free water. The $S$. epidermidis is encapsulated and nonhemolytic; $E$. coli 0127: B8 is encapsulated, serum resistant, and nonhemolytic. After overnight shaking, cultures were centrifuged and washed three times in pyrogen-free saline, and then bacteria were killed by boiling for $20 \mathrm{~min}$. After two further washings, aliquots of the bacterial suspensions were adjusted to $1.0 \times 10^{10}$ organisms $/ \mathrm{ml}$, and stored at $-70^{\circ} \mathrm{C}$ until used in experiments. The concentration of bacteria was determined spectrophotometrically, and confirmed by counting viable colonies using pour plate techniques before boiling. Direct microscopic counting of the bacteria was also used. The LPS content of the supernatant from the last washing was $<10 \mathrm{pg} / \mathrm{ml}$ based on the U. S. Standard Endotoxin (EC-5; Bureau of Biologics, Bethesda, MD) in both S. epidermidis and E. coli preparations, as measured by Limulus amebocyte lysate test with a sensitivity of $10 \mathrm{pg} / \mathrm{ml}$ (Associates of Cape Cod, Woods Hole, MA).

Rabbit model. The rabbit model was prepared according to the methods described previously (3) with minor modifications. Female New Zealand White rabbits $(4.1 \pm 0.3 \mathrm{~kg})$ were housed for a minimum of a week in the animal care facilities of the New England Medical Center and were free of infections. The rabbits were anesthetized with an initial intramuscular injection of $6 \mathrm{mg} / \mathrm{kg}$ xylazine and $20 \mathrm{mg} / \mathrm{kg}$ ketamine followed by $10 \mathrm{mg} / \mathrm{kg}$ ketamine injection i.m. every hour. Catheters (American Edwards Laboratories, Irvine, CA) were placed in the ascending aorta ( $3 \mathrm{~F}$ thermodilution probe) from the right carotid artery, the superior vena cava from the right jugular vein, and the abdominal aorta from the left femoral artery, to continuously record mean arterial pressure (MAP) and central venous pressure (CVP), and to measure cardiac output (CO). Hemodynamic parameters were recorded every $20 \mathrm{~min}$, and blood sampling was made hourly, unless otherwise stated, from the arterial line with the same volume of saline as replacement. The total fluid (saline) administered to each animal during the study was $5 \mathrm{ml} / \mathrm{kg}$ per $\mathrm{h}$. CO was measured by the thermodilution method; systemic vascular resistance (SVR) was calculated as follows: (MAP-CVP) $80 / \mathrm{CO}\left(\mathrm{dyn} \cdot \mathrm{s} \cdot \mathrm{cm}^{-5}\right)$. After the insertion of the catheters, hemodynamic parameters were monitored for $60 \mathrm{~min}$. After these $60 \mathrm{~min}$, hemodynamic parameters were measured and expressed as percent change of the value at $t=0 \mathrm{~min}$. The bacteria were thawed and resuspended in $10 \mathrm{ml}$ of sterile saline at various concentrations, and then infused into the superior vena cava over $20 \mathrm{~min}$ beginning at $=0 \mathrm{~min}$ while monitoring MAP. The bacteria were infused slowly to avoid a direct effect on hemodynamic parameters.
In vitro TNF and IL-1 production by rabbit peripheral blood mononuclear cells. Heat-killed $S$. epidermidis, heat-killed $E$. coli, LTA, and LPS were compared for their ability to induce the production of TNF and IL-1 in vitro. Rabbit PBMC were isolated by Ficoll-Hypaque centrifugation as previously described (26), and incubated in 96-well microtiter plates at a concentration of $5.0 \times 10^{6} \mathrm{cells} / \mathrm{ml}$ for $24 \mathrm{~h}$ in RPMI 1640 containing $1 \mu \mathrm{g} / \mathrm{ml}$ of indomethacin with differing doses of the bacteria, LTA, or LPS (E. coli 0127: B8; Sigma Chemical Co., St. Louis, MO). For comparison, each stimulus was preincubated with 5 $\mu \mathrm{g} / \mathrm{ml}$ of polymyxin B (PMB, clinical grade; Pfizer, Inc., New York) for $1 \mathrm{hr}$ at room temperature, then added to PBMC to block the effect of LPS. LTA was prepared from $S$. epidermidis and characterized by previously published procedures $(28,29)$. Total TNF and IL-1 production by PBMC were determined after three cycles of freeze-thawing, as previously described (26).

$T N F$ and $I L-1$ assay. TNF activity was measured by cytotoxicity in L929 murine fibroblasts, as described elsewhere (26). In brief, after an 18-h incubation of L929 cells in 96-well microtiter plates at $4.0 \times 10^{4}$ cells per well, culture medium was removed, and recombinant human TNF (kindly provided by Genentech Inc., South San Francisco, CA) as the standard, or samples were added with actinomycin D $(1 \mu \mathrm{g} / \mathrm{well})$. Serum samples were diluted 10 - to 1,000 -fold with RPMI, whereas in vitro TNF production by PBMC was determined by using 5 to 20 -fold dilution of the samples. The cells were stained with $0.1 \%$ crystal violet in $100 \%$ methanol and the OD at $595 \mathrm{~nm}$ was measured with a Microplate Reader (Bio-Rad Laboratories, Richmond, CA). The units of TNF were calculated based on the cytotoxicity of known concentrations of TNF in the standard curve of the same assay.

Rabbit IL- $1 \alpha$ and IL- $1 \beta$ were determined by specific RIAs (27) using goat antibodies raised against recombinant rabbit IL- $1 \alpha$ or IL-1 $\beta$, as described previously (30). Plasma samples collected in EDTA and aprotinin were assayed in the RIAs after two chloroform extractions to optimize detection of circulating IL-1, as previously described (31). The sensitivity of rabbit IL- $1 \alpha$ RIA and IL- $1 \beta$ RIA were 25-50 and $90-180 \mathrm{pg} / \mathrm{ml}$, respectively (95\% confidence level) (27).

Determination of complement activation. Complement activation was determined by assay of total hemolytic activity and serum C5a-like neutrophil aggregating activity according to the method described previously (32) with minor modification. In brief, total complement activity was measured by the hemolysis of sensitized sheep erythrocytes (DIAMEDIX, Miami, FL). Diluted (1:300) serum samples were incubated at $37^{\circ} \mathrm{C}$ for $1 \mathrm{~h}$ with sensitized sheep erythrocytes, then the $O D$ $(405 \mathrm{~nm})$ of the supernates was determined spectrophotometrically after centrifugation. Percent hemolysis was calculated by standard techniques. Total hemolytic complement activity at each time point is expressed as the percent of the hemolytic activity present at $t=0 \mathrm{~min}$.

Serum C5a-like activity was determined by aggregometry using rabbit neutrophils. $50 \mu \mathrm{l}$ of serum was added to $500 \mu \mathrm{l}$ of a suspension of cytochalasin-B-treated rabbit neutrophils in HBSS at a concentration of $5.0 \times 10^{6} \mathrm{cells} / \mathrm{ml}$. Aggregation was measured in a standard platelet aggregometer (Payton Scientific Inc., Buffalo, NY), and percent aggregating activity was expressed as the maximum increment in light transmission observed for a sample, divided by the maximum increment produced by the maximally activated rabbit serum (serum incubated with zymosan, $4 \mathrm{mg} / \mathrm{ml}$, for $30 \mathrm{~min}$ at $37^{\circ} \mathrm{C}$ ).

Histological studies. At the end of the experimental period $(300$ min after bacterial infusion), rabbits were sacrificed for necropsy with intravenous sodium pentobarbital injection. The tissues were removed, and fixed in buffered $10 \%$ formalin (pH 7.4). Tissues were dehydrated, imbedded in Parablast (Sigma), cut into 3-4- $\mu \mathrm{m}$ sections, and mounted. After removing the paraffin, tissues were stained with hematoxylin and eosin. Brown and Brenn stain was performed in some sections.

Data analyses. Results were expressed as the mean \pm standard error of mean. Statistical significance was determined by one-way analysis of variance for multiple groups, unless otherwise stated, using Stat-View software (Abacus Concepts, Inc., Calabasas, CA) on a Macintosh computer (Apple Computer, Inc., Cupertino, CA). 


\section{Results}

S. epidermidis induces hypotension and cytokinemia in a dosedependent fashion. Control animals infused with saline at $t=0$ min maintained stable hemodynamic parameters over $6 \mathrm{~h}$ of continuous monitoring (see Fig. $4 C$ ), although the hematocrit decreased as a result of serial blood sampling and volume replacement with saline (data not shown). MAP for five rabbits was $66.4 \pm 1.8 \mathrm{mmHg}$ at $t=0 \mathrm{~min}$ (saline infusion); $63.4 \pm 3.2$ at $t=180 \mathrm{~min}$; and $63.2 \pm 2.2$ at $t=300 \mathrm{~min}$. Serum TNF and plasma IL-1 $\beta$ levels did not differ from measurements before the saline infusion. When administered at a dose of $1.0 \times 10^{10}$ organisms $/ \mathrm{kg}$, S. epidermidis infusion did not change hemodynamic parameters significantly from preinjection measurements ( $n=6$, data not shown). In response to this dose of $S$. epidermidis, serum TNF levels increased significantly from $3.7 \pm 1.3 \mathrm{U} / \mathrm{ml}$ to $22.4 \pm 3.9 \mathrm{U} / \mathrm{ml}$ at $t=60 \mathrm{~min}(P<0.05)$, whereas plasma IL- $1 \beta$ levels did not differ significantly from a baseline level ( $t=0 \mathrm{~min}$ ) before the $S$. epidermidis infusion.

The dose of $S$. epidermidis was then doubled to $2.0 \times 10^{10} /$ $\mathrm{kg}$. Although hemodynamic parameters became unstable, they did not reach a statistically significant difference from the value at $t=0 \mathrm{~min}$ (Fig. $1 \mathrm{~A}$ ). Serum TNF reached peak levels after 60 min of $57.0 \pm 14.4 \mathrm{U} / \mathrm{ml}(P<0.05)$, and plasma IL- $1 \beta$ levels increased to a peak level of $328.8 \pm 60.6 \mathrm{pg} / \mathrm{ml}$ at $t=180 \mathrm{~min}$ (Fig. $1 B$ ). When the dose was increased to $5.0 \times 10^{10}$ of $S$. epidermidis $/ \mathrm{kg}$, transient hypotension from $t=40 \mathrm{~min}$ to $t$ $=220$ min was observed, accompanied by a decrease in SVR (Fig. $2 A$ ). MAP and SVR decreased maximally to $-25.7 \pm 2.2 \%$ $(P<0.01)$ and $-27.5 \pm 3.3 \%(P<0.01)$, respectively, at the same time $(t=140 \mathrm{~min})$, then began to increase. MAP returned to nearly preinfusion levels $(P>0.05$ from the value at $t=0)$, whereas SVR remained decreased $(P<0.05)$, with a statistically significant increase in CO at $t=280$ and $300 \mathrm{~min}(P$ $<0.05$ ). The mean peak serum TNF level was 123.2 $\pm 43.0 \mathrm{U} /$ $\mathrm{ml}$ at $t=60 \mathrm{~min}$, and remained significantly elevated at $t=120$ min (Fig. $2 B$ ). Plasma IL- $1 \beta$ levels were increased significantly at $t=120 \mathrm{~min}$, and reached a maximum elevation of $458.3 \pm 83.0 \mathrm{pg} / \mathrm{ml}$ at $t=180 \mathrm{~min}$ (Fig. $2 B$ ).

A further doubling of the dose to $1.0 \times 10^{11} \mathrm{~S}$. epidermidis/ $\mathrm{kg}$ resulted in severe and sustained hypotension, depicted in Fig. $3 \mathrm{~A}$. The maximal fall of MAP occurred at $t=180 \mathrm{~min}$ $(36.0 \pm 1.8 \mathrm{mmHg},-41.2 \pm 5.4 \% ; P<0.01)$, and was associated with the maximal decrease in SVR $(-38.7 \pm 5.6 \% ; P<0.01)$. CO remained unchanged $(P>0.05)$, with a slight decrease in CVP $(-1.3 \pm 0.2 \mathrm{mmHg} ; P<0.05)$ at $t=220$ and $240 \mathrm{~min}$. These rabbits developed rhinorrhea, conjunctival discharge, and diarrhea during the experiment, and peritoneal fluid accumulation was also noted at necropsy. These observations are consistent with endothelial injury and capillary leak resulting in water sequestration from vascular beds and requiring, in turn, a large fluid replacement (33).

As shown in Fig. $3 B$, the peak serum TNF level was $179.3 \pm 48.3 \mathrm{U} / \mathrm{ml}$ at $t=60 \mathrm{~min}$, and $127.3 \pm 37.7 \mathrm{U} / \mathrm{ml}$ at $t$ $=120 \mathrm{~min}$. This dose of $S$. epidermidis also induced a high and sustained elevation of IL- $1 \beta(1.6 \pm 0.5 \mathrm{ng} / \mathrm{ml}$ at $t=120 \mathrm{~min}$, $2.4 \pm 0.7 \mathrm{ng} / \mathrm{ml}$ at $t=180 \mathrm{~min}, 2.3 \pm 1.0 \mathrm{ng} / \mathrm{ml}$ at $t=240 \mathrm{~min}$, $1.0 \pm 0.4 \mathrm{ng} / \mathrm{ml}$ at $t=300)(P<0.05$ from $t=0)$ (Fig. $3 B$ ). Plasma IL- $1 \alpha$ was found in the same samples, as determined by the rabbit IL-1 $\alpha$ RIA (27) and showed good correlation ( $r$ $=0.84, P<0.001)$ with plasma IL- $1 \beta$ levels, although at $\sim 2.5$ fold lower concentrations.
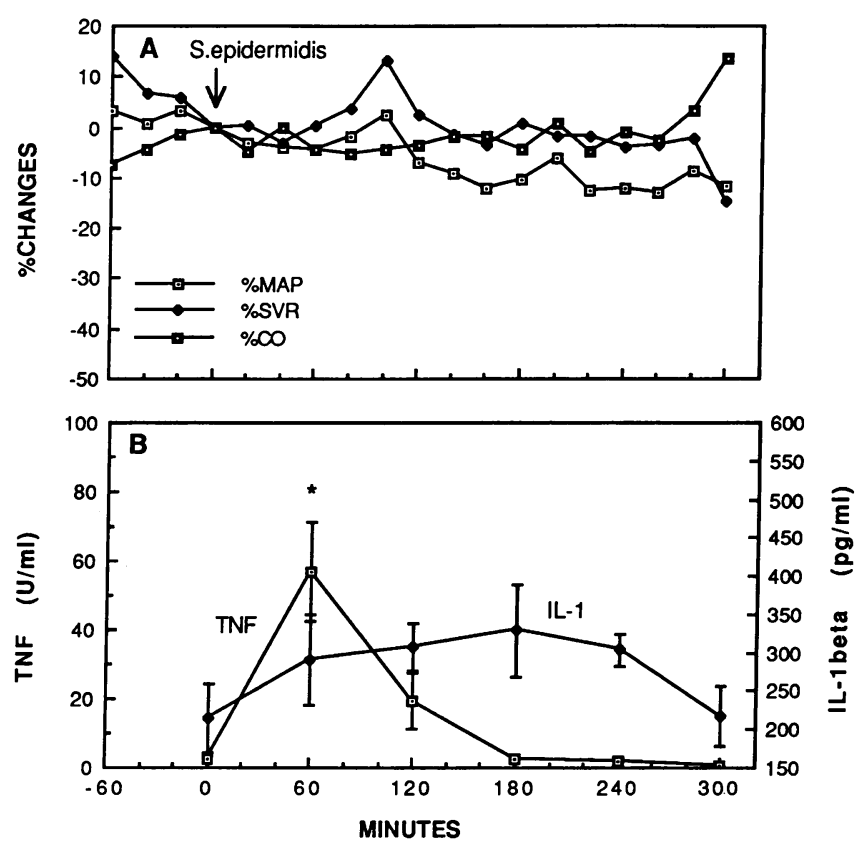

Figure 1. Hemodynamic parameters and circulating cytokine (TNF and IL-1 $\beta$ ) levels in rabbits infused with heat-killed $S$. epidermidis, $2 \times 10^{10} / \mathrm{kg}$. $(A)$ Mean percent changes from the value at $t=0 \mathrm{~min}$ for MAP, CO, and SVR. $(B)$ Serum TNF levels and plasma IL-1 $\beta$ levels. Data are presented as mean \pm SEM for four rabbits. Asterisk represents $P<0.05$ when compared to $t=0$.

Comparison with $E$. coli infusion. We next examined these changes induced by Gram-negative bacteremia, in which LPS is believed to play an important role. Using identical techniques, rabbits were given an infusion of heat-killed $E$. coli.

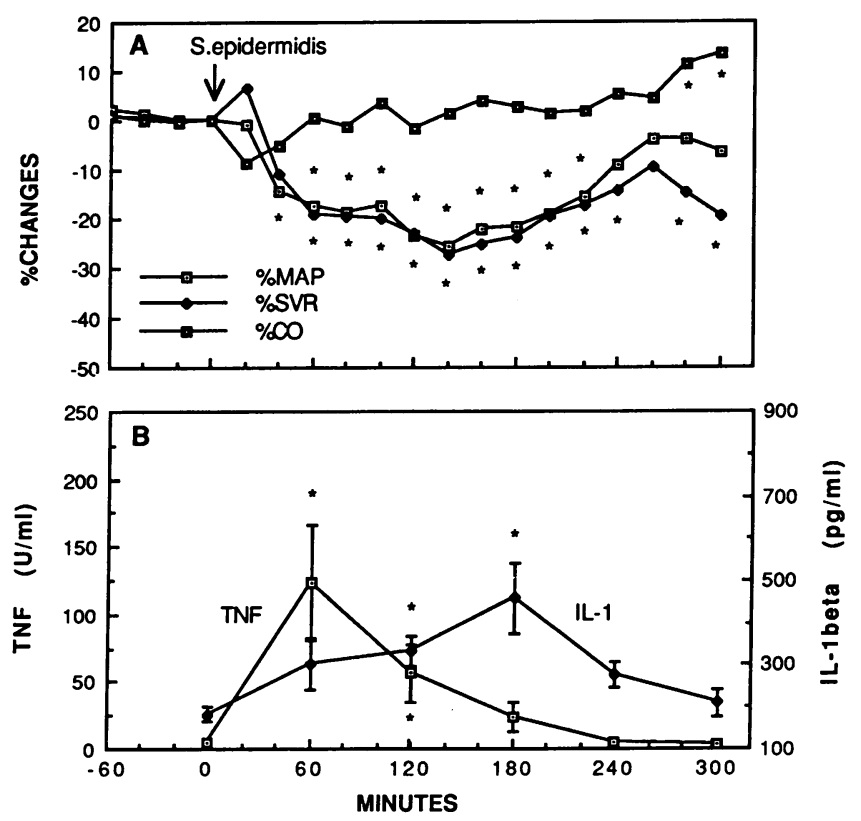

Figure 2. Hemodynamic parameters and circulating TNF and IL-1 $\beta$ levels in rabbits infused with heat-killed $S$. epidermidis, $5 \times 10^{10} / \mathrm{kg}$. $(A)$ Mean percent changes from the value at $t=0 \mathrm{~min}$ for MAP, CO, and SVR. (B) Serum TNF levels and plasma IL-1 $\beta$ levels. Data are presented as mean \pm SEM for six rabbits. Asterisks represent $P<0.05$ when compared to $t=0$. 

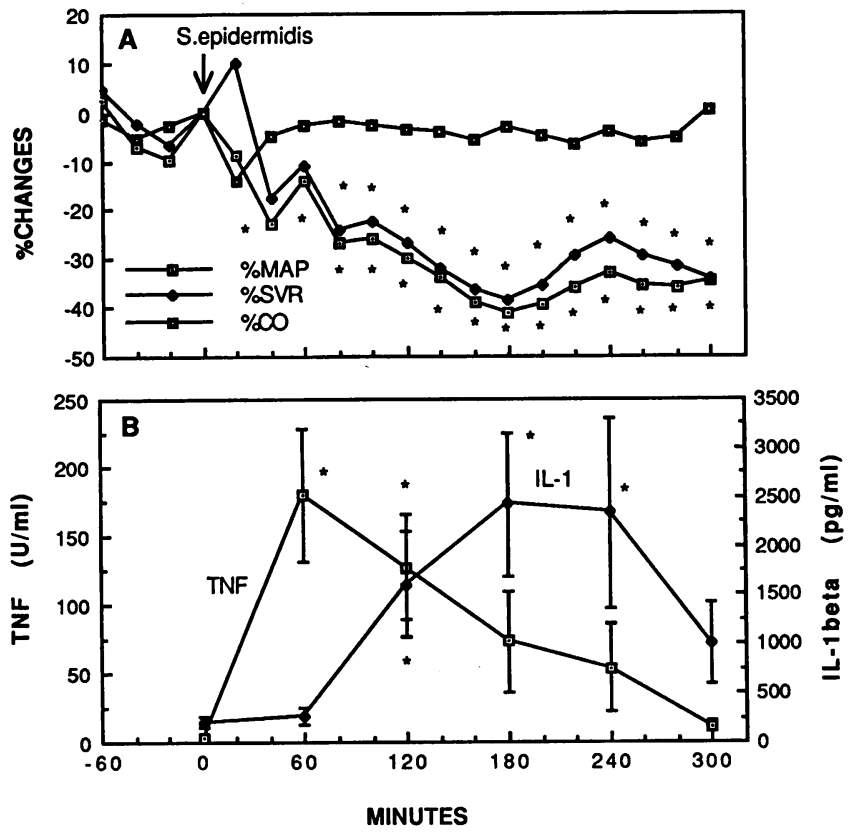

Figure 3. Hemodynamic parameters and circulating TNF and IL-1 $\beta$ levels in rabbits infused with heat-killed $S$. epidermidis, $1 \times 10^{11} / \mathrm{kg}$. $(A)$ Mean percent changes from the value at $t=0 \mathrm{~min}$ for MAP, CO, and SVR. $(B)$ Serum TNF levels and plasma IL- $1 \beta$ levels. Data are presented as mean \pm SEM for four rabbits. Asterisks represent $P<0.05$ when compared to $t=0$.

Initial studies indicated that the same degree of hypotension seen in rabbits infused with the high dose of $S$. epidermidis was observed in rabbits infused with one-twentieth the dose of $E$. coli. A dose of $5.0 \times 10^{9}$ of $E$. coli $/ \mathrm{kg}$ was chosen for further study. Fig. 4, $A$ and $B$, shows that this number of $E$. coli induces hemodynamic changes and increases in circulating TNF and IL-1 $\beta$ levels to the same degree as does high dose $S$. epidermidis. Fig. $4 A$ depicts the maximal fall of MAP (35.0 \pm 3.0 $\mathrm{mmHg},-41.2 \pm 3.9 \% ; P<0.01)$ and SVR $(-40.6 \pm 8.3 \% ; P$ $<0.02)$ which occurred at the same time $(t=280 \mathrm{~min})$ in these rabbits. There was no significant difference in the hemodynamic parameters between high dose $S$. epidermidis and $E$. coli infused animals (Fig. $4 C$ ) except the percent $\mathrm{CO}$ at $t=100 \mathrm{~min}$ (S. epidermidis; $97.0 \pm 1.4 \%$ vs. $E$. coli; $91.7 \pm 1.0 \% ; P<0.05$ ). Serum TNF reached peak levels of $193.3 \pm 47.4 \mathrm{U} / \mathrm{ml}$ at $t=60$ min, then declined to $99.3 \pm 29.8 \mathrm{U} / \mathrm{ml}$ at $t=120 \mathrm{~min}$, and $55.8 \pm 25.7 \mathrm{U} / \mathrm{ml}$ at $t=180 \mathrm{~min}$ (Fig. $4 \mathrm{~B}$ ). Peak IL- $1 \beta$ levels of $1.7 \pm 0.7 \mathrm{ng} / \mathrm{ml}$ were measured at $t=.180 \mathrm{~min}$, and $1.4 \pm 0.7$ $\mathrm{ng} / \mathrm{ml}$ at $t=240 \mathrm{~min}$ (Fig. $4 \mathrm{~B}$ ). Interestingly, the peak IL-1 $\beta$ levels tended to be lower in rabbits infused with $E$. coli than in rabbits following high dose $S$. epidermidis, although the peak TNF levels and the degree of hypotension did not differ in either group.

Correlation between hemodynamic parameters and circulating cytokine levels. Correlations were analyzed between hemodynamic parameters and circulating cytokine levels at the same time points. The hyperbolic shape of these data suggested that they could be transformed to the inversion of circulating cytokine levels before analysis by simple linear regression. As shown in Fig. 5, $A$ and $B$, a high degree of correlation was observed between MAP and the reciprocal of circulating IL- $1 \beta$
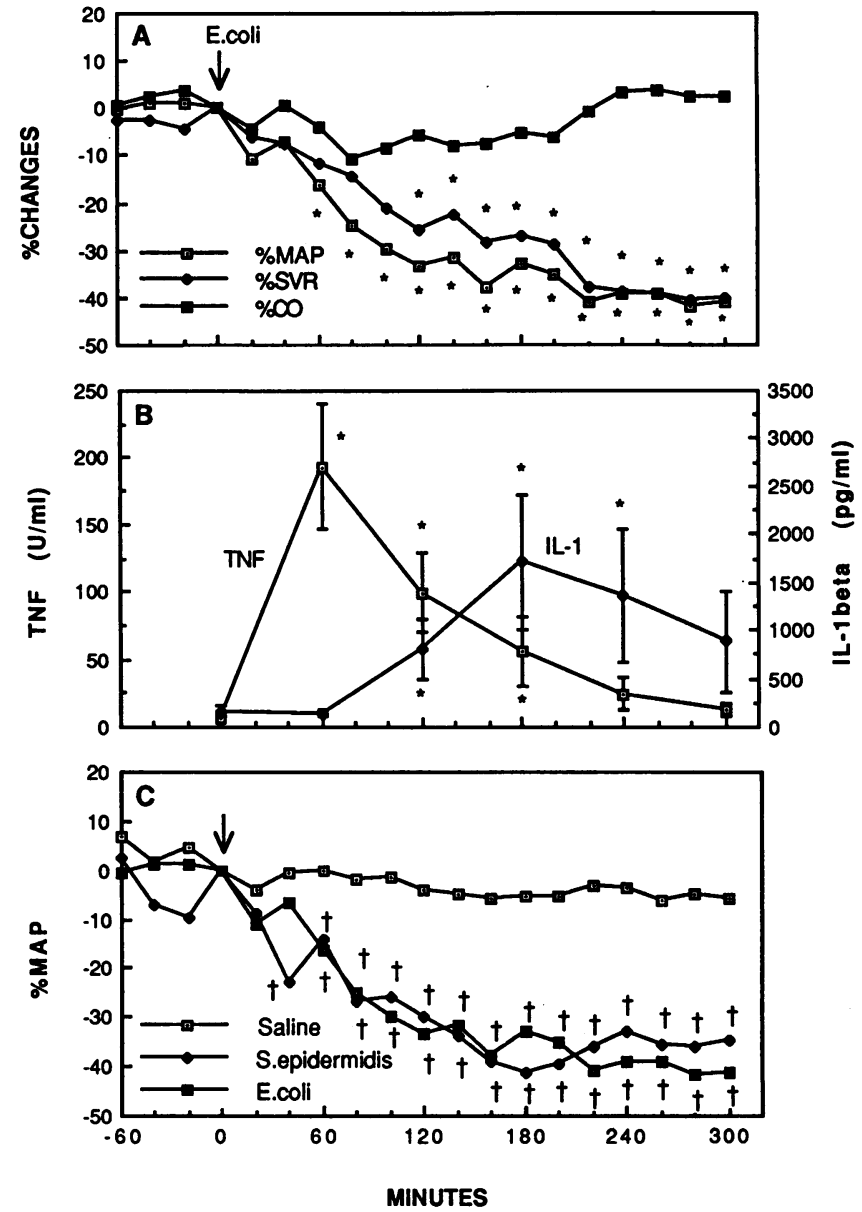

Figure 4. Hemodynamic parameters and circulating TNF and IL-1 $\beta$ levels in rabbits infused with heat-killed $E$. coli, $5.0 \times 10^{9} / \mathrm{kg}$, and comparison of changes in MAP induced by $S$. epidermidis or $E$. coli. $(A)$ Mean percent changes from the value at $t=0 \mathrm{~min}$ for MAP, CO, and SVR. $(B)$ Serum TNF levels and plasma IL-1 $\beta$ levels. Data are presented as mean \pm SEM for four rabbits. $(C)$ Comparison of changes in MAP induced by saline, heat-killed $S$. epidermidis, $1 \times 10^{11} / \mathrm{kg}$, or heat-killed $E$. coli, $5.0 \times 10^{9} / \mathrm{kg}$. Asterisks represent $P<0.05$ when compared to $t=0$. Latin crosses indicate that the values from bacterial infusions are significantly $(P<0.05)$ different from the corresponding saline injection values at the same time points.

levels in rabbits infused with a high dose of $S$. epidermidis ( $r$ $=0.811, P=0.0001$ ), whereas a lesser degree of correlation was found between MAP and the reciprocal of circulating TNF levels in the same animal group $(r=0.477, P=0.0185)$. Similarly, correlations were noted between SVR and the reciprocal of IL-1 levels in the same group $(r=0.626, P=0.0011)$. In rabbits infused with $E$. coli, a good correlation was also observed between MAP and the reciprocal of IL- $1 \beta(r=0.682, P$ $=0.0002)$; however, the reciprocal of circulating TNF levels did not correlate with MAP $(r=0.078, P=0.7181)$.

Complement activation after bacterial infusion. Complement activation was observed in both groups of animals infused with either high dose $S$. epidermidis or 20-fold less $E$. coli. Complement depletion was sustained over the whole period of the experiment (Fig. $6 \mathrm{~A}$ ). The percent of hemolysis of sheep erythrocytes was maximal at $t=0$ and then decreased significantly $(P<0.05)$ at $t=60 \mathrm{~min}$ and $t=300 \mathrm{~min}$ (serum 

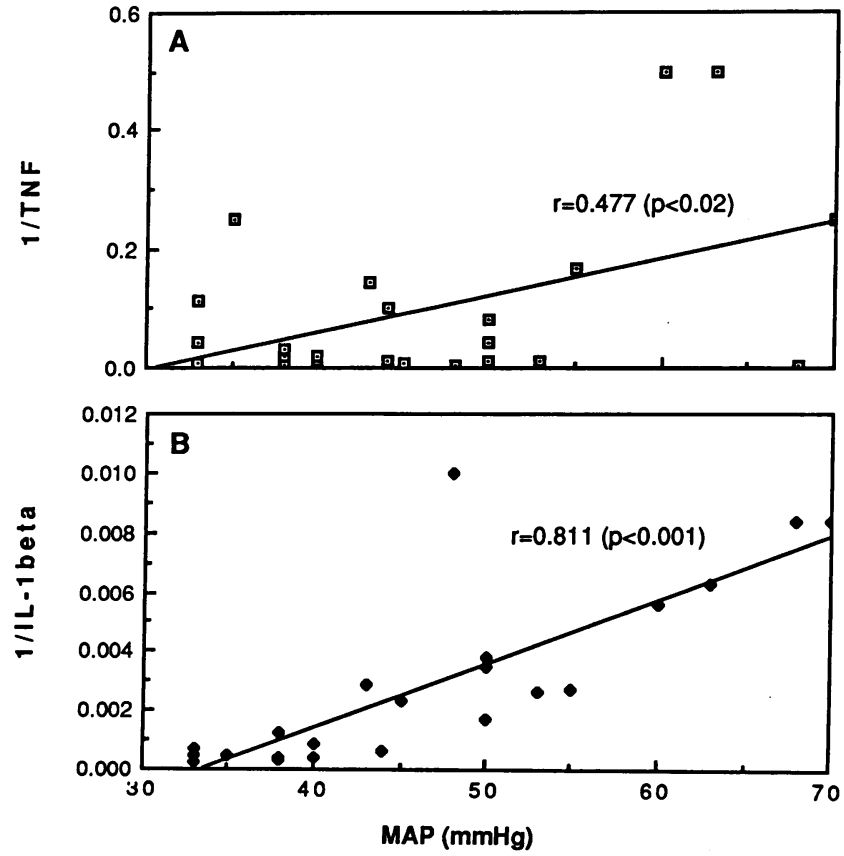

Figure 5. Correlation between serum TNF and plasma IL-1 $\beta$ levels with changes in MAP at the time of blood sampling. Rabbits infused with heat-killed $S$. epidermidis, $1 \times 10^{11} / \mathrm{kg}$, were bled each hour for cytokine levels. 24 samples from four rabbits were assayed for TNF $(A)$, and by specific RIA for rabbit IL-1 $\beta(B)$ after two chloroform extractions. Circulating cytokine levels were transformed to the reciprocal for simple linear regression analysis.

from rabbits given $S$. epidermidis) and at $t=120 \mathrm{~min}, t=240$ min, and $t=300$ (serum from rabbits infused with $E$. coli).

Serum C5a-like activity as measured by neutrophil aggregometry increased rapidly after either bacterial infusion (Table I). As shown in Fig. $6 B$, significant $(P<0.05)$ aggregation was produced by serum obtained at $t=30 \mathrm{~min}$ and $60 \mathrm{~min}$ from rabbits infused with $1.0 \times 10^{11} \mathrm{~S}$. epidermidis $/ \mathrm{kg}$, and at $t=60$ min from rabbits infused with $5.0 \times 10^{9} \mathrm{E}$. coli $/ \mathrm{kg}$. In most neutrophil aggregation assays, peak aggregation was observed in samples obtained at $t=30 \mathrm{~min}$, and then aggregation diminished gradually at further time points. Samples from control animals (saline infusion at $t=0 \mathrm{~min}$ ) induced $<20 \%$ of maximum aggregation at any time point. There was no significant difference in the degree of aggregation produced by serum obtained from either $S$. epidermidis or $E$. coli-infused animals.

Table I. Percent Neutrophil Aggregation Induced by Serum Obtained from Rabbits Infused with Saline,

$S$. epidermidis, or E. coli

\begin{tabular}{lc}
\hline \multicolumn{1}{c}{ Treatment } & $\begin{array}{c}\text { Percent of maximum } \\
\text { aggregation }(t=60 \mathrm{~min})\end{array}$ \\
\hline Saline & $18.8 \pm 6.3$ \\
S. epidermidis & $44.4 \pm 6.4^{*}$ \\
E. coli & $43.0 \pm 13.0$
\end{tabular}

${ }^{*} P<0.04$ when compared to the saline injected control value $(t=60$ $\min$ ) by one-tail $t$ test.
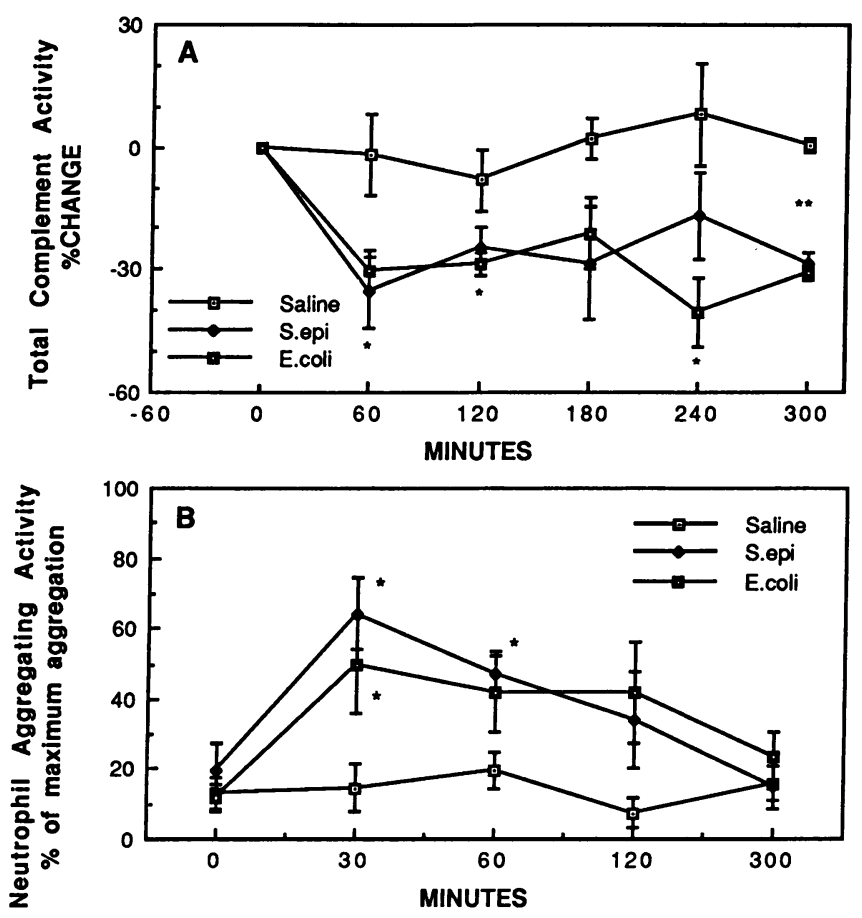

Figure 6. Complement activation as reflected by depletion of total hemolytic complement activity and serum C5a-like neutrophil aggregating activity after bacterial infusions of either saline, heat-killed $S$. epidermidis, $1 \times 10^{11} / \mathrm{kg}$, or heat-killed $E$. coli, $5.0 \times 10^{9} / \mathrm{kg}$. $(A)$ Total complement hemolytic activity is expressed as percent change of the percent hemolysis at $t=0 \mathrm{~min}$, as described in Methods. (B) Neutrophil aggregating activity is expressed as percent of maximum neutrophil aggregation produced by zymosan activated rabbit serum, as described in Methods. Data are presented as mean \pm SEM for four rabbits. Asterisks signify $P<0.05$ when compared to the corresponding saline injection value at the same time point. Double asterisks indicate that both values after either bacterial infusion are decreased significantly $(P<0.05)$ from the corresponding saline-injected control value at the same time point.

Serum endotoxin levels and complete blood counts. Serum LPS levels were measured by the Limulus amebocyte lysate test. Serum was first diluted 1:5 with pyrogen-free saline and heated to $100^{\circ} \mathrm{C}$ for $10 \mathrm{~min}$ to reduce the effect of nonspecific inhibitors (34). Most serum samples from saline and S. epidermidis-infused animals were below the detection limit, but due to the dilution, an undetectable value was assigned a value five times the detection limit of the assay (i.e., $\sim 50 \mathrm{pg} / \mathrm{ml}$ ). As shown in Fig. 7, following $S$. epidermidis infusions, there were no significant changes in the endotoxin levels $(52.5 \pm 1.4 \mathrm{pg} / \mathrm{ml}$, $t=0 ; 56.3 \pm 2.4 \mathrm{pg} / \mathrm{ml}, t=60 ; 60.0 \pm 5.4 \mathrm{pg} / \mathrm{ml}, t=300 \mathrm{~min}) ;$ on the other hand, injections of killed and washed $E$. coli were associated with significant elevation of serum LPS levels $(1,150 \pm 42 \mathrm{pg} / \mathrm{ml}, t=60 ; 838 \pm 374 \mathrm{pg} / \mathrm{ml}, t=300 \mathrm{~min})$.

The white blood cell (WBC) and platelet counts were evaluated in rabbits infused with saline, $S$. epidermidis, or $E$. coli. Rabbits infused with either $1.0 \times 10^{11} \mathrm{~S}$. epidermidis $/ \mathrm{kg}$ or 5.0 $\times 10^{9} \mathrm{E}$. coli $/ \mathrm{kg}$ developed severe leukopenia and thrombocytopenia. The nadir of the WBC counts occurred at $t=180 \mathrm{~min}$ (S. epidermidis; $-63.5 \pm 5.9 \%$ of the value at $t=0 \mathrm{~min}, E$. coli; $-52.8 \pm 9.7 \%)$. Platelet counts fell maximally at $t=60 \mathrm{~min}(S$. epidermidis; $-82.8 \pm 3.8 \%$ of the value at $t=0 \mathrm{~min}, E$. coli; 


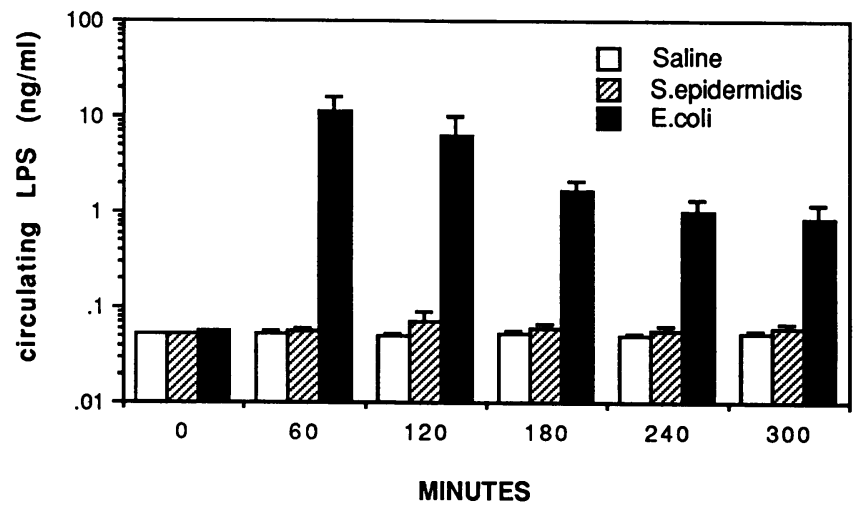

Figure 7. Serum LPS levels after infusion of either saline, heat-killed S. epidermidis, $1 \times 10^{11} / \mathrm{kg}$, or heat-killed E. coli, $5.0 \times 10^{9} / \mathrm{kg}$.

$-66.5 \pm 2.6 \%$ ). Similar to the other parameters, the percent changes did not differ at any time points between animals infused with either $S$. epidermidis or $E$. coli.

Tissue studies. Gross anatomical and microscopic abnormalities were similar in rabbits infused with either high dose $S$. epidermidis or 20-fold less $E$. coli. Gross abnormalities were confined to the lungs that showed focal or diffuse hyperemia. Microscopic sections of the lungs revealed engorgement of capillaries with erythrocytes and polymorphonuclear leukocytes, including some in aggregates. Margination of neutrophils in larger pulmonary vessels was also observed. The livers showed acute hepatocellular necrosis and diffuse infiltration of neutrophils with neutrophil aggregates in the sinusoids. Necrosis was multifocal with embolic or miliary like distribution, and was confined to single or small clusters of hepatocytes (Fig. $8 \mathrm{~A}$ ). There was disruption of hepatic cords with necrosis and acute inflammatory cells (Fig. $8 \mathrm{~B}$ ) which had the appearance of early "microabscesses." Although the bacteria used in this study were not viable, the appearance of the liver was similar to that seen in patients with overwhelming sepsis. The kidneys showed cellular aggregates of neutrophils, platelets, and fibrin within small intrarenal veins (Fig. $8 \mathrm{C}$ ). Histologic examination of the heart, lungs, liver, spleen, kidneys, and gastrointestinal tracts of rabbits infused with saline revealed no abnormalities.

Tissue Gram-stain (Brown-Brenn stain) disclosed dissemination of Gram-positive cocci in the lungs, liver, spleen, and kidneys of rabbits receiving $S$. epidermidis via the superior vena caval infusion. These cocci were localized to resident macrophages, Kupffer cells (Fig. $8 \mathrm{D}$ ), intravascular mononuclear phagocytes, and neutrophils (Fig. $8 C$ ). These microorganisms were particularly prominent within the neutrophil aggregates in the lungs, liver, and in the microabscesses of the liver. Grampositive cocci were also observed in glomerular capillaries (Fig. $8 E$ ) and intrarenal veins.

In vitro $T N F$ and $I L-1$ production in response to $S$. epidermidis, $E$. coli, LTA, or LPS. TNF, IL- $1 \alpha$, and IL- $1 \beta$ were synthesized by rabbit PBMC in response to either $S$. epidermidis, $E$. coli, LTA, or LPS. The potency of each stimulus to induce these cytokines differed. For the same number of bacteria, cytokine production by $E$. coli-stimulated PBMC was approximately two to five times greater than that by $S$. epidermidis (Fig. 9). Cytokine production increased in a dose-dependent fashion with increasing bacterial number. At the linear portion of the curve, a 10 - to 100 -fold greater number of $S$. epidermidis was required to induce the same level of cytokine as $E$. coli.
As shown in Fig. 10, LTA also induced TNF and IL-1 $\alpha$ production by PBMC in a dose-dependent fashion, without being affected by PMB. PMB significantly reduced the potency of $E$. coli, but decreased the potency of LPS to a greater degree. No effect was seen by PMB on cytokine production induced by either $S$. epidermidis or LTA (Fig. 9 and Fig. 10). The amount of TNF induced by $100 \mu \mathrm{g} / \mathrm{ml}$ of LTA was nearly equal to that induced by $1 \mu \mathrm{g} / \mathrm{ml}$ of LPS. The dose-response curve for LPS levels off at $100 \mathrm{ng} / \mathrm{ml}$ whereas LTA induced a sharp increase from 10 to $100 \mu \mathrm{g} / \mathrm{ml}$.

\section{Discussion}

Models for septic shock syndrome have usually employed LPS or Gram-negative bacteria. However, the syndrome can also occur during the course of Gram-positive bacteremia (19-23) and the prognosis for patients with Gram-negative or positive bacteremias does not differ greatly $(35,36)$. Natanson et al. (25) demonstrated that Staphylococcus aureus, in the absence of endotoxemia, induced the same cardiovascular abnormalities of septic shock as $E$. coli in the dog, suggesting that distinct microorganisms or their products activate common mediators of the shock syndrome. Activated complement, PAF, and cytokines are likely mediators in inducing shock during Gramnegative bacteremia, and these studies demonstrate that $S$. epidermidis induces a shock-like state with a similar degree of complement activation and cytokine generation, but in the absence of endotoxemia.

The amount and the time course of complement activation, cytokine generation, and hypotension induced by $S$. epidermidis were nearly identical to those induced by $E$. coli. The hemodynamic derangements induced by either bacterium were characteristic of hyperdynamic septic shock (33). IL-1 and TNF levels correlated well $(r=0.81$ and $r=0.48$, respectively) with the degree of hypotension, whether induced by $S$. epidermidis or $E$. coli. Thus, septic shock does not require the participation of endotoxin, as Natanson et al. (25) suggested, but rather is linked to an overexpression of host factors, whether induced by Gram-negative or Gram-positive bacteria.

We compared the potency of $S$. epidermidis to $E$. coli in inducing TNF and IL-1 production. One-twentieth the number of $E$. coli was equipotent to $S$. epidermidis in inducing complement activation, cytokine generation, and hypotension in vivo. During in vitro cytokine production by rabbit PBMC, a 10 - to 100 -fold greater number of heat-killed $S$. epidermidis was required to obtain the same level of cytokine production as heat-killed $E$. coli. Using heat-killed $S$. epidermidis, exotoxins that might contribute to disease in vivo (37) were likely destroyed whereas LPS is unaffected by heat. Lipoteichoic acid, a heat stable component of most Gram-positive bacteria with some properties similar to LPS (28) and peptidoglycan (38), likely contributed to TNF and IL-1 production. However, LTA is less potent than LPS on a weight basis. LTA induction of IL-1 and TNF was not due to contaminating LPS. In contrast, LPS is still present in the heat-killed $E$. coli organisms.

Another stimulant of cytokine synthesis is activated complement. Complement activation was observed in both $S$. epidermidis and $E$. coli bacteremias. Serum C5a-like neutrophil aggregating activity increased rapidly within $30 \mathrm{~min}$ and this was followed by serum TNF levels that peaked $60 \mathrm{~min}$ after the injection of either bacteria. As TNF levels fell, plasma IL-1 $\beta$ 

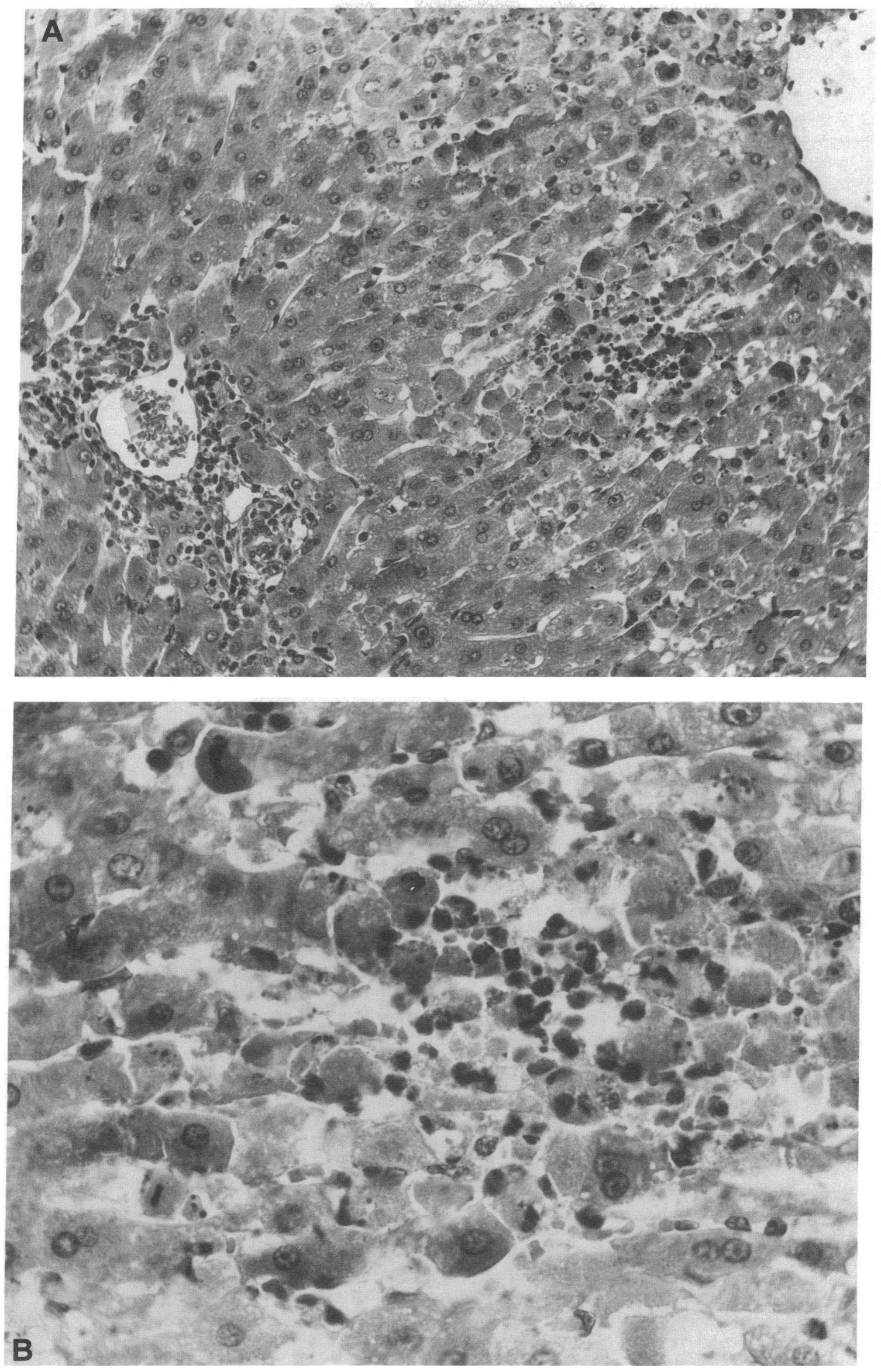

Figure 8 

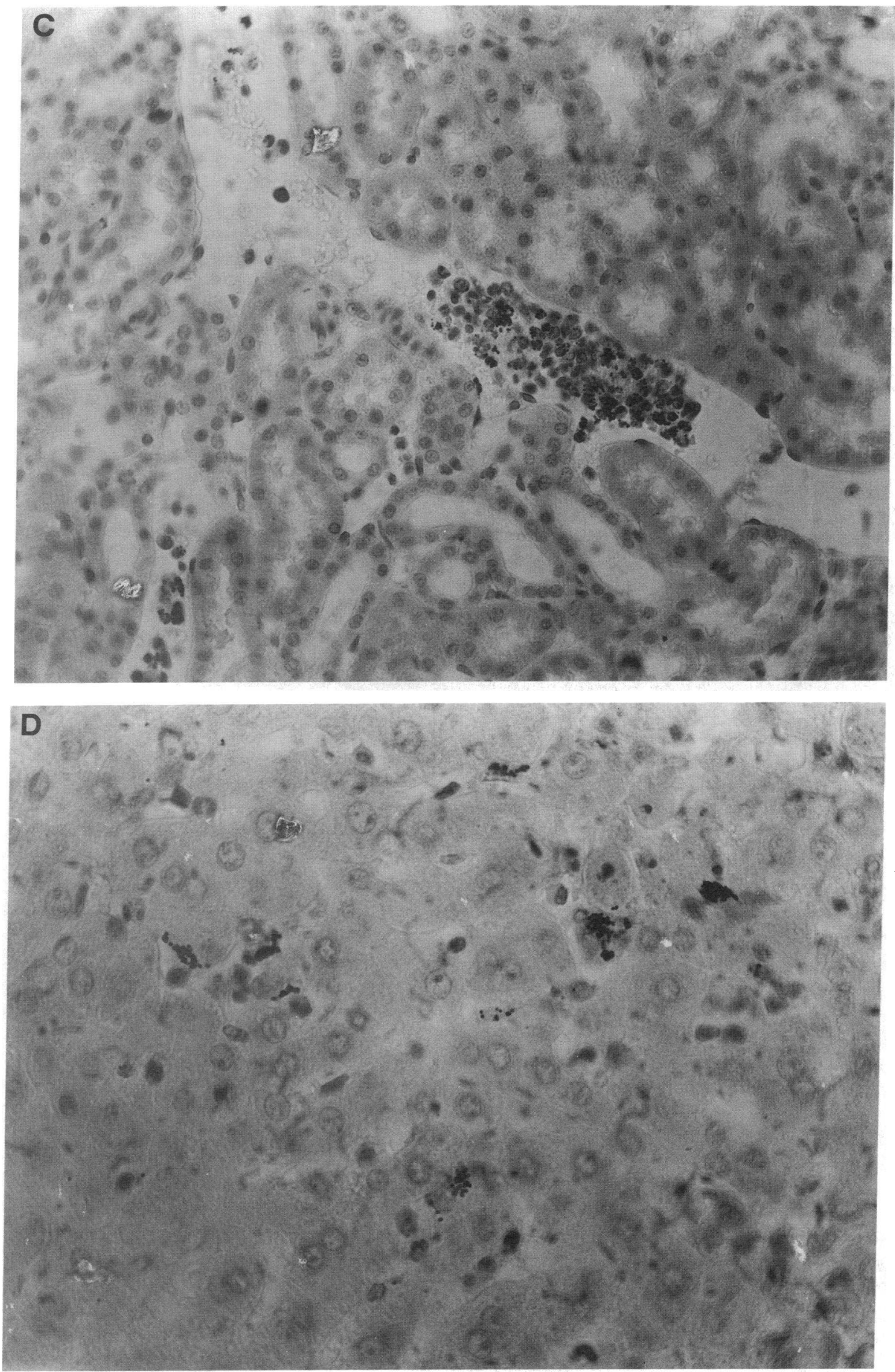

Figure 8 (Continued) 


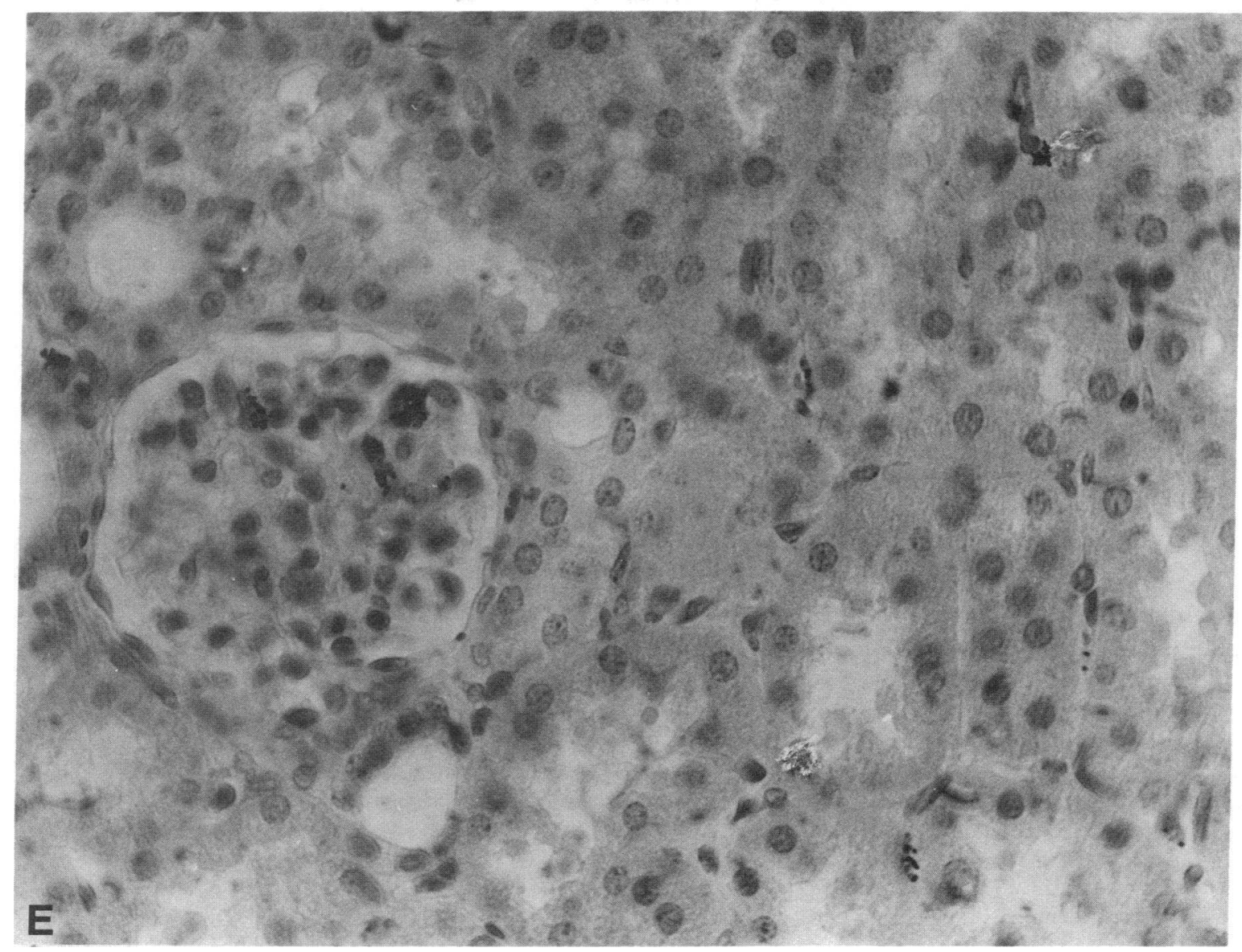

Figure 8. Histological appearance of tissues obtained from a rabbit infused with $1 \times 10^{11} / \mathrm{kg}$ heat-killed $S$. epidermidis. $(A)$ Section of liver showing focus of acute hepatic necrosis $(\times 400$, hematoxylin-eosin stain). (B) Section of liver showing disruption of hepatic cords with necrosis and acute inflammatory cells $(\times 500$, hematoxylin-eosin stain). $(C)$ Section of kidney showing intravascular cell aggregates with fibrin $(\times 500$, Brown-Brenn stain). (D) Section showing stained organisms located in the sinusoids and in Kupffer cells $(\times 500$, Brown-Brenn stain). (E) Section showing stained organisms found in glomerular capillaries ( $\times 500$, Brown-Brenn stain).

increased to peak levels $180 \mathrm{~min}$ after the infusion. The appearance and duration of circulating TNF and IL-1 are nearly the same as those measured during experimental human endotoxemia or experimental $E$. coli bacteremia in animals $(18,39-$ 41). Since C5a induces TNF (42) and IL-1 (43) in vitro, our observation of complement activation associated with either $E$. coli or $S$. epidermidis followed by elevation of these cytokines in the circulation suggests that complement activation in vivo provides one of the triggers for cytokine production. IL-1 and TNF themselves may also contribute to cytokine production. Injection of recombinant IL-1 or TNF into rabbits induces the appearance of each other in the circulation $(44,45)$. This cytokine autoamplification is apparently also taking place during $E$. coli sepsis in baboons since pretreatment with neutralizing antibodies to TNF reduces circulating IL-1 levels (18).

The cytokine autoamplification event may be important in the pathogenesis of the shock syndrome and particularly in producing tissue damage. In these studies, we observed areas of focal tissue injury with neutrophil aggregates, intravascular coagulation, and fibrin deposition in rabbits injected with heatkilled $S$. epidermidis. In endothelial cells, TNF and IL-1 induce each other's synthesis, procoagulant activity (46), and increased neutrophil adherence to endothelial cells (47) which likely contribute to tissue damage. In the absence of bacteria, tissue damage has been observed following TNF (1) but particularly the combination of IL-1 and $\operatorname{TNF}(3,48)$. Thus, the coinduction of cytokines at the tissue level may be an important event in cytokine-mediated tissue injury.

An important part of these studies was to correlate IL-1 production with hemodynamic changes during non-endotoxin-induced shock in the rabbit. Since many of the hemodynamic changes associated with the septic shock syndrome in humans and larger animals are not observed in the rabbit, and since the bolus injection of organisms compresses the effects of sepsis into a relatively short period of time, the rabbit clearly has limitations, and the model is vulnerable to over interpretation. However, the rabbit is well-suited for studying the production of and responses to IL-1 and TNF, even in the anesthetized state. Using specific RIA's, it was possible to quantitate IL-1 production during either $E$. coli or $S$. epidermidis bacteremia and correlate these levels with the degree of hypotension. Are these correlations valid? The rabbit, although anesthetized, and humans have similar dose responses to the biological effects of intravenously injected IL-1; for example, the pyrogenic response to IL-1 is $10-100 \mathrm{ng} / \mathrm{kg}$ in both species $(30,49,50)$. The rabbit develops hypotension following $1-5 \mu \mathrm{g} / \mathrm{kg}$ of human IL-1 (3), and systemic blood pressure falls $35 \%$ in baboons given IL-1 at $1 \mu \mathrm{g} / \mathrm{kg}$. Humans become hypotensive at 100 

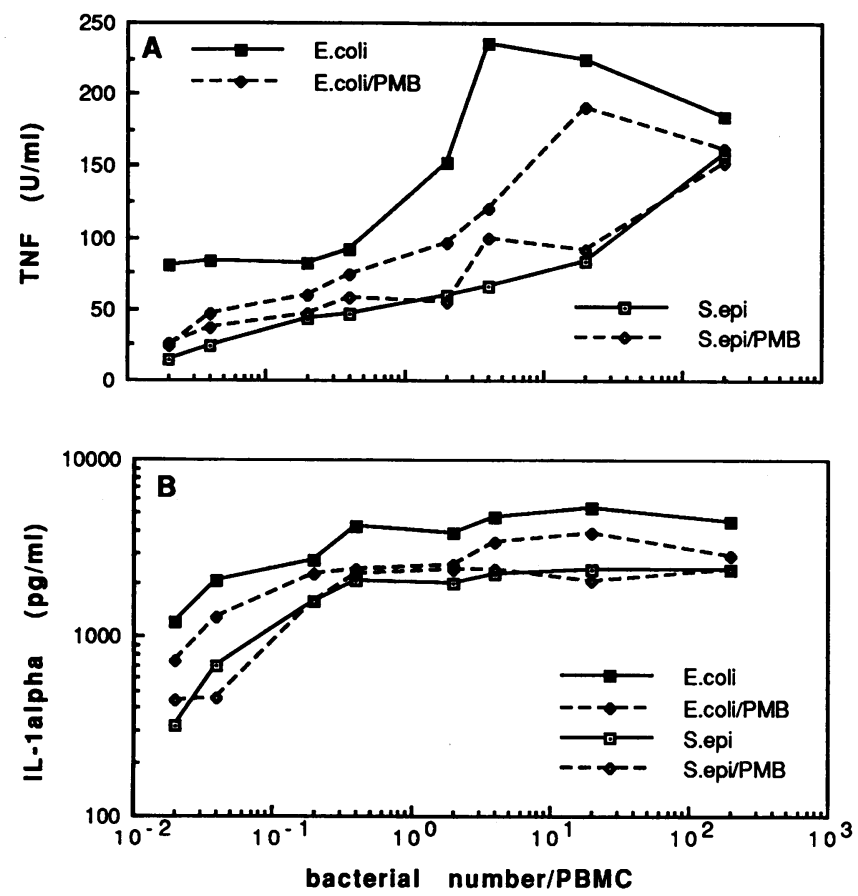

Figure 9. In vitro TNF and IL- $1 \alpha$ production by rabbit PBMC stimulated with different concentrations of heat-killed $S$. epidermidis or $E$. coli. All incubations were performed in the absence or presence of $5 \mu \mathrm{g} / \mathrm{ml}$ PMB. Total cytokine production (supernatants plus cell lysates) after a 24-h incubation was determined by the L929 assay for TNF $(A)$, or specific RIA for rabbit IL-1 $\alpha(B)$. Similar results were obtained in two additional experiments.
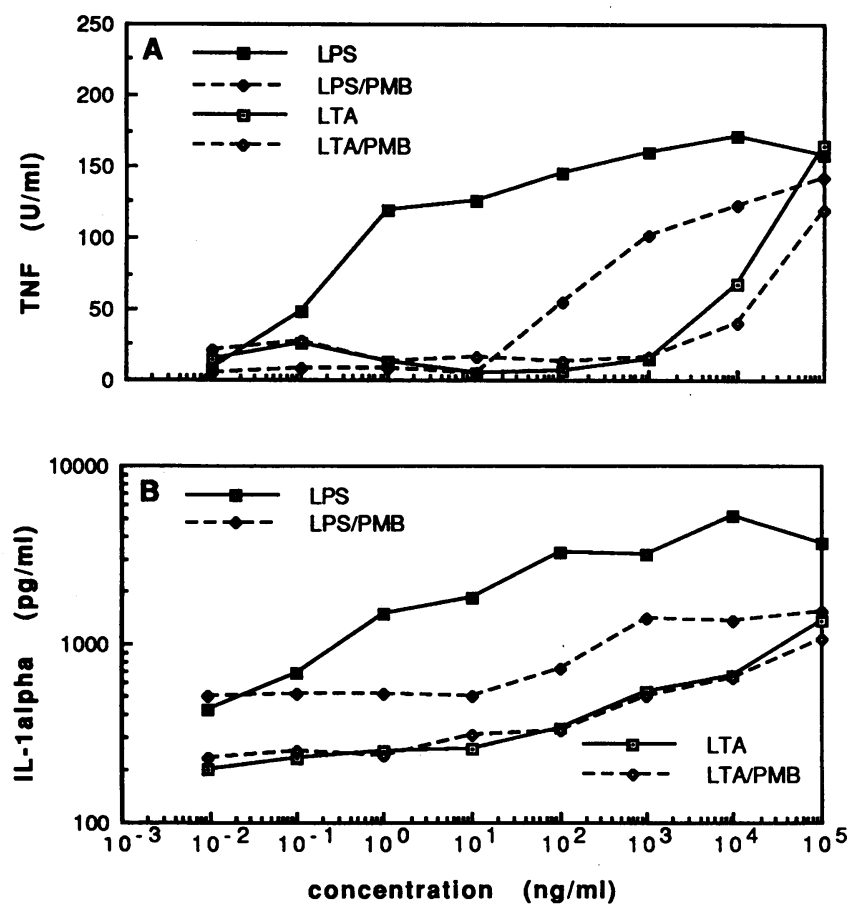

Figure 10. In vitro TNF and IL-1 $\alpha$ production by rabbit PBMC stimulated with different concentrations of LTA or LPS. All incubations were performed under the same conditions as described in the legend to Fig. 9. Similar results were obtained in an additional experiment. ng-1.0 $\mu \mathrm{g} / \mathrm{kg}$ and severe (stage IV) hypotension was observed following a single intravenous injection of $1 \mu \mathrm{g} / \mathrm{kg}$ (50). Hypotension is, in fact, the dose-limiting toxicity (at $300 \mathrm{ng} / \mathrm{kg}$ ) for IL-1 in human trials. Similar to IL-1, the rabbit dose response to the pyrogenic (44) and hypotensive effect of TNF (3) is similar to those published in several clinical trials.

In this study, we have shown that IL-1 levels correlate with the degree of hypotension regardless of the presence of endotoxemia, but other studies have provided evidence for an essential role for IL-1 in the septic shock syndrome. The IL-1 receptor antagonist that blocks only IL-1 binding to its cell surface receptor prevents lethality of LPS and the hypotension of $E$. coli bacteremia in rabbits $(51,52)$; these effects of the IL-1 receptor antagonist have also been observed in baboons given viable $E$. coli (Moldawer, L.; personal communication). Although TNF has been shown to be a critical mediator of septic shock syndrome, the present data support the concept that IL-1 also plays important role, and is required for the evolution of this fatal syndrome.

\section{Acknowledgments}

The authors thank Michael V. Callahan, Isabelle Bedrosian, and Katherine Kimball for technical assistance. We acknowledge Dr. Burton D. Clark and Dr. Joseph G. Cannon for their valuable contribution to this work regarding the development of the radioimmunoassay for rabbit interleukin-1. We also thank Silvia Judd and Carol McClarey for secretarial assistance.

This study was supported in part by grants AI-15614 and GM21700 from the National Institutes of Health, and by the Louviers Foundation. Dr. G. Wakabayashi is a recipient of a Career Development Award from the Uehara Memorial Foundation.

\section{References}

1. Tracy, K. J., B. Beutler, S. F. Lowry, J. Merryweather, S. Wolpe, I. W. Milsark, R. J. Hariri, T. J. Fahey III, A. Zentella, J. D. Albert, et al. 1986. Shock and tissue injury induced by recombinant human cachectin. Science (Wash. DC). 234:470-474.

2. Tracy, K. J, S. F. Lowry, T. J. Fahey III, J. D. Albert, Y. Fong, D. Hesse, B. Beutler, K. R. Manogue, S. Calvano, H. Wei, et al. 1987. Cachectin/tumor necrosis factor induces lethal shock and stress hormone responses in the dog. Surg. Gynecol. \& Obstet. 164:415-422.

3. Okusawa, S., J. A. Gelfand, T. Ikejima, R. J. Connolly, and C. A. Dinarello. 1988. Interleukin-1 induces a shock-like state in rabbits. Synergism with tumor necrosis factor and the effect of cyclooxygenase inhibition. J. Clin. Invest. 81:1162-1172.

4. Weinberg, J. R., D. J. M. Wright, and A. Guz. 1988. Interleukin-1 and tumor necrosis factor cause hypotension in the conscious rabbit. Clin. Sci. (Lond.). 75:251-255.

5. Tredget, E. E., Y. M. Yu, S. Zhong, R. Burini, S. Okusawa, J. A. Gelfand, C. A. Dinarello, V. R. Young, and J. F. Burke. 1988. Role of interleukin-1 and tumor necrosis factor on energy metabolism in rabbits. Am. J. Physiol. 255:E760-E768.

6. Girardin, E., G. E. Grau, J-M. Dayer, P. Roux-Lombard, the J5 Study Group, and P. Lambert. 1988. Tumor necrosis factor and interleukin-1 in the serum of children with severe infectious purpura. $N$. Engl. J. Med. 319:397-400.

7. Pavek, K., P. J. Piper, and G. Smedegard. 1979. Anaphylatoxin-induced shock and two patterns of anaphylactic shock: hemodynamics and mediators. Acta Physiol. Scand. 105:393-403.

8. Lundberg, C., F. Marceau, and T. E. Hugli. 1987. C5a-induced hemodynamic and hematologic changes in the rabbit: role of cyclooxygenase products and polymorphonuclear leukocytes. Am. J. Pathol. 128:471-483.

9. Stevens, J. H. P. O'Hanley, J. M. Shapiro, F. G. Mihm, P. S. Satoh, J. A. Collins, and T. A. Raffin. 1986. Effects of anti-C5a antibodies on the adult respiratory distress syndrome in septic primates. J. Clin. Invest. 77:1812-1816.

10. Smedegard, G., L. Cui, and T. E. Hugli. 1989. Endotoxin-induced shock in the rat: a role for C5a. Am. J. Pathol. 135:489-497.

11. Fearon, D. T., S. Ruddy, P. H. Schur, and W. R. McCabe. 1975. Activation of the properdin pathway of complement in patients with Gram-negative bacteremia. N. Engl. J. Med. 292:937-940. 
12. Bessin, P., J. Bonnet, D. Apffel, C. Soulard, I. Desgroux, I. Pelas, and J. Benveniste. 1983. Acute circulatory collapse caused by platelet-activating factor in dogs. Eur. J. Pharmacol. 86:403-413.

13. Terashita, Z., Y. Imura, K. Nishikawa, and S. Sumida. 1985. Is platelet activating factor (PAF) a mediator of endotoxin shock? Eur. J. Pharmacol. 109:257-261.

14. Doebber, T. W., M. S. Wu, J. C. Robbins, B. M. Choy, M. N. Chang, and T. Y. Shen. 1985. Platelet-activating factor involvement in endotoxin-induced hypotension in rats: studies with PAF-receptor antagonist kadsurenone. Biochem. Biophys. Res. Commun. 127:799-808.

15. Beutler, B., I. W. Milsark, and A. C. Cerami. 1985. Passive immunization against cachectin/tumor necrosis factor protects mice from lethal effect of endotoxin. Science (Wash. DC). 229:869-871.

16. Tracy, K., Y. Fong, D. G. Hesse, K. R. Manogue, A. T. Lee, G. C. Kuo, S. F. Lowry, and A. Cerami. 1987. Anti-cachectin/TNF monoclonal antibodies prevent septic shock during lethal bacteremia. Nature (Lond.). 330:662-664.

17. Mathison, J. C., E. Wolfson, and R. J. Ulevitch. 1988. Participation of tumor necrosis factor in the mediation of Gram negative bacterial lipopolysaccharide-induced injury in rabbits. J. Clin. Invest. 81:1925-1937.

18. Fong, Y., K. J. Tracey, L. L. Moldawer, D. G. Hesse, K. B. Manogue, J. S. Kenney, A. T. Lee, G. C. Kuo, A. C. Allison, S. F. Lowry, and A. Cerami. 1989. Antibodies to cachectin/tumor necrosis factor reduce interleukin $1 \beta$ and interleukin 6 appearance during lethal bacteremia. J. Exp. Med. 170:1627-1633.

19. Christensen, G. D., A. L. Bisno, J. T. Parisi, B. McLaughlin, M. G. Hester, and R. Wayne Luther. 1982. Nosocomial septicemia due to multiply antibioticresistant Staphylococcus epidermidis. Ann. Intern. Med. 96:1-10.

20. Burchard, K. W., L. B. Minor, G. J. Slotman, and D. S. Gann. 1984. Staphylococcus epidermidis sepsis in surgical patients. Arch. Surg. 119:96-100.

21. Ponce de Leon, S., and R. P. Wenzel. 1984. Hospital-acquired bloodstream infections with Staphylococcus epidermidis. Review of 100 cases. Am. J. Med. 77:639-644

22. Martin, M. A., M. A. Pfaller, and R. P. Wenzel. 1989. Coagulase-negative staphylococcal bacteremia. Mortality and hospital stay. Ann. Intern. Med. 110:916.

23. Smith, I. M. 1981. Staphylococcus epidermidis septicemia: 1974-1978 compared to 1949-1958. In Staphylococci and Staphylococcal Infections. J. Jeljaszewicz, editor. Gustav Fischer Verlag, New York. 765-772.

24. Nafziger, D. A., and R. P. Wenzel. 1989. Coagulase-negative staphylococci: epidemiology, evaluation, and therapy. In Infectious Disease Clinics of North America. D. J. Weber and W. A. Rutala, editors. W. B. Saunders Co., Philadelphia. 915-929.

25. Natanson, C., R. L. Danner, R. J. Elin, J. M. Hosseini, K. W. Peart, S. M: Banks, T. J. MacVittie, R. I. Walker, and J. E. Parrillo. 1989. Role of endotoxemia in cardiovascular dysfunction and mortality. Escherichia coli and Staphylococcus aureus challenges in a canine model of human septic shock. J. Clin. Invest. 83:243-251

26. Ikejima, T., S. Okusawa, J. W. M. van der Meer, and C. A. Dinarello. 1988. Induction by toxic-shock-syndrome toxin-1 of a circulating tumor necrosis factor-like substance in rabbits and of immunoreactive tumor necrosis factor and interleukin-1 from human mononuclear cells. J. Infect. Dis. 158:1017-1025.

27. Clark, B. D., I. Bedrosian, R. Schindler, F. Cominelli, J. G. Cannon, A. R Shaw, and C. A. Dinarello. 1990. Levels of interleukin- $1 \alpha$ and $\beta$ in various tissues during endotoxemia in rabbits using sensitive radioimmunoassays. J. Appl. Physiol. In press.

28. Wicken, A. J., and K. W. Knox. 1975. Lipoteichoic acids: a new class of bacterial antigen. Science (Wash. DC). 187:1161-1167.

29. Tojo, M., N. Yamashita, D. A. Goldmann, and G. B. Pier. 1988. Isolation and characterization of a capsular polysaccharide adhesin from Staphylococcus epidermidis. J. Infect. Dis. 157:713-722.

30. Cannon, J. G., B. D. Clark, P. Wingfield, U. Schmeissner, C. Losberger, C. A. Dinarello, and A. R. Shaw. 1989. Rabbit IL-1. Cloning, expression, biologic properties, and transcription during endotoxemia. J. Immunol. 142:2299-2306.

31. Cannon, J. G., J. M. W. van der Meer, D. Kwiatkowski, S. Endres, G Lonnemann, J. F. Burke, and C. A. Dinarello. 1988. Interleukin- $1 \beta$ in human plasma: optimization of blood collection, plasma extraction and radioimmunoassay methods. Lymphokine Res. 7:457-467.

32. Simon, G. L., J. A. Gelfand, R. A. Connolly, T. F. O'Donnell, and S. L. Gorbach. 1985. Experimental Bacteroides fragilis bacteremia in primate model: evidence that Bacteroides fragilis does not promote the septic shock syndrome. $J$. Trauma. 25:1156-1162.
33. Parker, M. M., and J. E. Parrillo. 1983. Septic shock. Hemodynamics and pathogenesis. JAMA (J. Am. Med. Assoc.). 250:3324-3327.

34. Cohen, J., and J. S. McConnell. 1984. Observations on the measurement and evaluation of endotoxemia by a quantitative limulus lysate microassay. $J$. Infect. Dis. 150:916-924.

35. Gunnar, R. M., H. S. Loeb, E. J. Winslow, C. Blain, and J. Robinson 1973. Hemodynamic measurements in bacteremia and septic shock in man. $J$. Infect. Dis. 128:S295-S298.

36. Bone, R. C., C. J. Fisher, Jr., T. P. Clemmer, G. J. Slotman, C. A. Metz R. A. Balk, and The Methylprednisolone Severe Sepsis Study Group. 1989. Sepsis syndrome: a valid clinical entity. J. Crit. Care. 17:389-393.

37. Gemmell, C. G. 1987. Exo-proteins of coagulase-negative staphylococci as possible virulence factors. In Handbook of Endotoxin. Vol. 1. Chemistry of Endotoxin. E. Th. Rietschel, editor. Suppl. 16. Gustav Fischer Verlag, New York. 93-102.

38. Oken, M. M., P. K. Peterson, and B. J. Wilkinson. 1981. Endogeneous pyrogen production by human blood monocytes stimulated by Staphylococcal cell wall components. Infect. Immun. 31:208-213.

39. Hesse, D. G., K. J. Tracey, Y. Fong, K. R. Manogue, M. A. Palladino, Jr., A. Cerami, G. Tom Shires, and S. F. Lowry. 1988. Cytokine appearance in human endotoxemia and primate bacteremia. Surg. Gynecol. \& Obstet. 166:147153.

40. Michie, H. R., K. R. Manogue, D. R. Spriggs, A. Revhaug, S. O’Dwyer, C. A. Dinarello, A. Cerami, S. M. Wolff, and D. W. Wilmore. 1988. Detection of circulating tumor necrosis factor after endotoxin administration. N. Engl. J. Med. 318:1481-1486.

41. Cannon, J. G., R. G. Tompkins, J. A. Gelfand, H. R. Michie, G. G. Stanford, J. W. M. van der Meer, S. Endres, G. Lonnemann, J. Corsetti, B. Chernow, et al. 1990. Circulating interleukin-1 and tumor necrosis factor in septic shock and experimental endotoxin fever. J. Infect. Dis. 161:79-84.

42. Okusawa, S., K. B. Yancey, J. W. M. van der Meer, S. Endres, G. Lonnemann, K. Hefter, M. M. Frank, J. F. Burke, C. A. Dinarello, and J. A. Gelfand 1988. C5a stimulates secretion of tumor necrosis factor from human mononuclear cells in vitro. Comparison with secretion of interleukin $1 \beta$ and interleukin 1a. J. Exp. Med. 168:443-448.

43. Okusawa, S., C. A. Dinarello, K. B. Yancey, S. Endres, T. J. Lawley, M. M. Frank, J. F. Burke, and J. A. Gelfand. 1987. C5a induction of human interleukin 1: synergistic effect with endotoxin or interferon- $\gamma . J$. Immunol. 139:2635-2640.

44. Dinarello, C. A., J. G. Cannon, S. M. Wolf, H. A. Bernheim, B. Beutler, A. Cerami, I. S. Figari, M. A. Palladino, Jr., and J. V. O'Connor. 1986. Tumor necrosis factor (cachectin) is an endogenous pyrogen and induces production of interleukin 1. J. Exp. Med. 163:1433-1450.

45. Ikejima, T., S. Okusawa, P. Ghezzi, J. W. M. van der Meer, and C. A. Dinarello. 1990. Interleukin-1 induces tumor necrosis factor in human peripheral blood mononuclear cells in vitro and a circulating TNF-like activity in rabbits. $J$. Infect. Dis. 162:215-223.

46. Bevilacqua, M. P., J. S. Pober, G. R. Majeau, W. Fiers, R. S. Cotran, and M. A Gimbrone, Jr 1986. Recombinant tumor necrosis factor induces procoagulant activity in cultured human vascular endothelium: characterization and comparison with actions of interleukin 1. Proc. Natl. Acad. Sci. USA. 83:4533-4537.

47. Pohlman, T. H , K A Stanness, P. G. Beatty, H. D Ochs, and J. M. Harlan. 1986. An endothelial cell surface factor(s) induced in vitro by lipopolysaccharide, interleukin 1 , and tumor necrosis factor- $\alpha$ increases neutrophil adherence by a CDw18-dependent mechanism. J. Immunol. 86:4548-4553.

48. Movat, H. Z., C. E. Burrowes, M. I. Cybulsky, and C. A. Dinarello. 1987. Acute inflammation and a Shwartzman-like reaction induced by interleukin-1 and tumor necrosis factor. Synergistic action of the cytokines in the induction of inflammation and microvascular injury. Am. J. Pathol. 129:463-476.

49. Tewari, A., W. C. Buhles, Jr., and H. F. Starnes, Jr. 1990. Preliminary report: effect of interleukin-1 on platelet counts. Lancet. ii:336:712-714.

50. Smith, J., II, W. Urba, R. Steis, J. Janik, B. Fenton, W. Sharfman, K Conlon, M. Sznol, S. Creekmore, N. Wells, et al. 1990. A phase I trial of interleukin-1 alpha(IL-1 $\alpha)$ alone and in combination with indomethacin. Lymphokine Res. 9:568 (Abstr.).

51. Ohlsson, K., P. Bjork, M. Bergenfeldt, R. Hageman, and R. C. Thompson. 1990. Interleukin-1 receptor antagonist reduces mortality from endotoxin shock. Nature (Lond.). 348:550-552.

52. Wakabayashi, G. J A Gelfand J. F Burke R C Thompson, and C. A Dinarello. 1991. A specific receptor antagonist for interleukin-1 prevents $E$. coli induced shock. FASEB (Fed. Am. Soc. Exp. Biol.) J. 5:338-343. 